\title{
A brief history of the study of fish osmoregulation: the central role of the Mt. Desert Island Biological Laboratory
}

\author{
David H. Evans ${ }^{1,2 *}$ \\ 1 Department of Biology, University of Florida, Gainesville, FL, USA \\ 2 Mount Desert Island Biological Laboratory, Salisbury Cove, ME, USA
}

Edited by:

Shigehisa Hirose, Tokyo Institute of Technology, Japan

Reviewed by:

Pung P. Hwang, Academia Sinica,

Taiwan

Greg G. Goss, University of Alberta,

Canada

\section{*Correspondence:}

David H. Evans, Department of

Biology, University of Florida, 317

Bartram Hall, Gainesville,

FL 32611, USA

e-mail:devans@ufl.edu
The Mt. Desert Island Biological Laboratory (MDIBL) has played a central role in the study of fish osmoregulation for the past 80 years. In particular, scientists at the MDIBL have made significant discoveries in the basic pattern of fish osmoregulation, the function of aglomerular kidneys and proximal tubular secretion, the roles of $\mathrm{NaCl}$ cotransporters in intestinal uptake and gill and rectal gland secretion, the role of the shark rectal gland in osmoregulation, the mechanisms of salt secretion by the teleost fish gill epithelium, and the evolution of the ionic uptake mechanisms in fish gills. This short review presents the history of these discoveries and their relationships to the study of epithelial transport in general.

Keywords: fish osmoregulation, kidney, gill, epithelial transport

\section{INTRODUCTION}

In 1921, the Harpswell Laboratory, which housed Tufts University's Summer School of Biology, moved to Mt. Desert Island, ME from South Harpswell, ME, where it had been functioning as a teaching and research laboratory since 1898. The property in Salisbury Cove had been purchased by the Wild Gardens of Acadia, a group of philanthropists led by George Dorr, who was instrumental in establishing much of Mt. Desert Island as the Acadia National Park. The relocated laboratory, called the Mt. Desert Island Biological Laboratory (MDIBL) after 1923, consisted of a single, two-story teaching laboratory that was modeled after the main building at Harpswell. Undergraduate courses continued to be taught at the MDIBL in its early years, but by the late 1920s, much of the teaching mission of the MDIBL had been replaced by research groups that were attracted to the local marine species, the scientific collegiality, and Maine island ambience. Thus, began over 80 years of research on various aspects of comparative physiology that has brought together collaborative researchers from various biomedical and biological departments throughout the US and overseas ${ }^{1}$. The intent of this review is to describe the history of six areas of research that have been important in the study of fish osmoregulation and epithelial transport in general. In each case, the research at the MDIBL has been central to what is presently known.

\section{THE BASIC PATTERN OF MARINE FISH OSMOREGULATION ${ }^{2}$}

By the late 1920s, it was known that marine teleost fishes were hypotonic to their surrounding seawater and could not produce urine more concentrated than the plasma (reviewed in Evans, 2008). There was some suggestion that marine teleosts might

${ }^{1}$ For an excellent review of MDIBL history and research to 1998, see Epstein (1998). ${ }^{2}$ More complete reviews of fish osmoregulation include Karnaky (1998), Marshall and Grosell (2006), and Evans and Claiborne (2009). ingest the medium, because fluid was often found in the intestine (Smith, 1930), but the suite of homeostatic mechanisms that teleosts employ in osmoregulation was unknown. Homer Smith studied the American eel (Anguilla rostrata) in his NYU lab and the sculpin (Myoxocephalus sp.) and goosefish (Lophius sp.) at the MDIBL. Using the volume marker phenol red, he demonstrated that both the sculpin and the eel ingested seawater, and, since the phenol red was concentrated in the gut, it was clear that the intestinal epithelium absorbed much of the ingested water. Since ligation of the pylorus abolished the appearance of phenol red in the intestine, it was settled that the intestinal dye entered the fish via the mouth, not by diffusion across the gills. Smith calculated that approximately $90 \%$ of the ingested fluid was excreted extrarenally, but he appeared to be unaware of the fact that the osmotic gradient across the gills would favor the osmotic withdrawal of water from the fish across the thin epithelium. By sampling gut fluids at various sites along the intestine, Smith found that the $\mathrm{Mg}^{2+}$ and $\mathrm{SO}_{4}^{2+}$ concentrations increased far above the level of even the surrounding seawater. The total osmolarity, however, decreased along the intestine (reaching approximate isotonicity with the fish plasma), suggesting that $\mathrm{NaCl}$ was absorbed in addition to water.

Importantly, Smith also confirmed early studies that the urine was "invariably" isotonic or even hypotonic to the plasma, and that, like the intestinal fluids, the urine contained high concentrations of $\mathrm{Mg}^{2+}$ and $\mathrm{SO}_{4}^{2+}$. It is interesting to note that Smith observed that the "osmotic pressure and inorganic composition" of the urine in the goosefish ("possesses a purely tubular kidney") was similar to that found in the eel and sculpin, both of which have glomerular kidneys. He concluded: "the osmotic pressure and inorganic composition of normal urine is not significantly dependent on the pressure or absence of glomeruli (Smith, 1930)." Since the $\mathrm{NaCl}$ concentration was relatively low in both intestinal fluids and urine, 
Smith concluded that extrarenal secretory mechanisms must exist, and suggested that the gills are the most likely site of extrarenal $\mathrm{NaCl}$ secretion. Thus, in a single publication, Smith proposed the basic outline of marine teleost fish osmoregulation: ingestion of seawater, retrieval of $\mathrm{NaCl}$ (and some $\mathrm{Mg}^{2+}$ and $\mathrm{SO}_{4}^{2}$ ) and water from the intestine, followed by excretion of the divalents via the urine, and the monovalents across the gills.

During this same period, Smith (1931) also worked out some of the osmoregulatory strategies of marine elasmobranchs . Using elasmobranch species available near the MDIBL, as well as some from the New York Aquarium, Smith confirmed that marine elasmobranch plasma was actually slightly hypertonic to seawater, and that the urine was usually hypotonic to the plasma. Thus, the elasmobranchs actually gain some water osmotically, which is balanced by the excretion of hypotonic urine. Smith also confirmed that the hypertonicity of the plasma was primarily the result of substantial concentrations of urea, which were maintained by urea reabsorption in the kidney. He also suggested that in marine elasmobranchs, like marine teleosts, the gills were the site of extrarenal excretion of $\mathrm{NaCl}$. The function of the rectal gland was not discovered until 1960, at the MDIBL; nevertheless, most of the basic strategies of marine elasmobranch osmoregulation had been worked out by Smith (Figure 1).

\section{AGLOMERULAR KIDNEYS AND PROXIMAL TUBULAR SECRETION}

E. K. Marshall came from Johns Hopkins to the MDIBL in the summer of 1926, because he was interested in proving his theories about renal tubular secretion by using the aglomerular goosefish, Lophius piscatorius. Working with Homer Smith ${ }^{3}$, Marshall measured the diameter of the renal corpuscle (glomerulus plus Bowman's capsule) in a variety of marine and freshwater teleosts. The corpuscles of freshwater fishes (e.g., carp, goldfish, trout, and perch) ranged from 60 to $106 \mu \mathrm{m}$ in diameter, and those of glomerular marine teleosts (e.g., sculpin, sea bass, cod, haddock, and flounder) ranged from 35 to $81 \mu \mathrm{m}$. Sixteen species (such as pipefish, seahorse, toadfish ${ }^{4}$, and

${ }^{3}$ Homer Smith had worked, periodically, with E. K. Marshall between 1918 and 1928 on the biological action of nerve gases and chemotherapeutic drugs, so it is likely that Smith was recruited to the MDIBL by Marshall.

${ }^{4}$ Surprisingly, the toadfish is euryhaline (Lahlou et al., 1969).

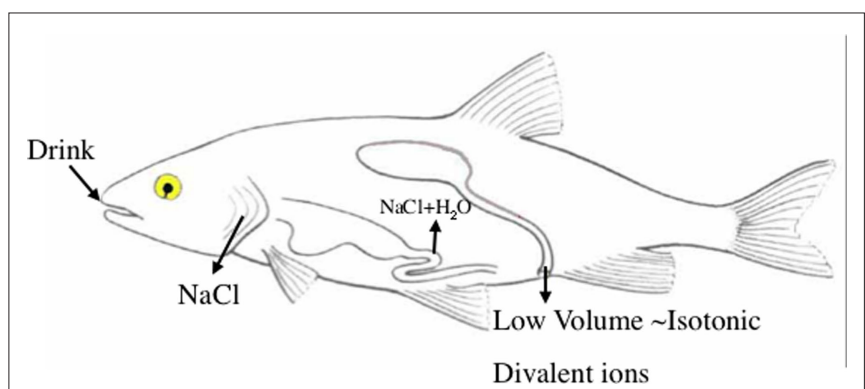

FIGURE 1 | Basic pattern of marine teleost osmoregulation. To offset the osmotic loss of water across the gill epithelium, the fish ingests seawater and absorbs $\mathrm{NaCl}$ and water across the esophageal and intestinal epithelium. Urinary water loss is kept to a minimum by production of a low volume of urine that is isotonic to the plasma, but contains higher concentrations of divalent ions than the plasma. Excess $\mathrm{NaCl}$ is excreted across the gill epithelium. Redrawn from Evans (2008). goosefish) were found to have no renal corpuscles (Marshall and Smith, 1930). Marshall also demonstrated that the urine flows he measured in the goosefish and toadfish were of the same order as those measured in glomerular, marine teleosts, such as the sculpin. In addition, his measurements of urine ionic $\left(\mathrm{Cl}^{-}, \mathrm{Mg}^{2+}, \mathrm{SO}_{4}^{2-}\right)$ and organic (urea and creatinine) constituents found no differences between glomerular and aglomerular species. Marshall concluded: "The present study proves unquestionably that the renal tubule can be excretory as well as reabsorptive in its function: that it can pass substances from the blood and lymph across the tubule into its lumen (Marshall, 1930).”

James Shannon (who worked in the Smith lab at NYU and MDIBL, and who later became the first Director of the NIH) invited Roy Forster to come to MDIBL in the summer of 1937 . Nearly 40 years later, at his retirement dinner (Forster, 1977), Forster talked about his amazement on the first day in Shannon's lab, when E. K. Marshall and Homer Smith both appeared. Forster initially used clearance techniques to study glomerular function, secretion, and reabsorption in the amphibian kidney, and also studied renal hemodynamics in rabbits. After WWII, Forster became interested in studying tubular secretion more directly by examining thin slices of kidney tissue, or isolated renal tubules using a technique that had been described earlier for the chicken kidney (Chambers and Kempton, 1933). His initial experiments demonstrated that functional tubules could be isolated from a variety of fish species (e.g., founder, killifish, and sculpin), but flounder tubules were the basis for much of the study. These tubules could concentrate phenol red to nearly $4000 \times$ that in the perfusate, and this secretion could be inhibited by cold, anoxia, cyanide, azide, dinitrophenol, and mercury (Forster and Taggart, 1950), demonstrating the energy requirements of this secretory process. More recently, this technique has been used to study the mechanisms and control of transport of various organic molecules across the flounder and killifish proximal tubules (e.g., Miller, 2002).

Using the isolated, perfused proximal tubule techniques first worked out in rabbit nephrons (Burg et al., 1966), and also used with flounder tubules at the MDIBL (Burg and Weller, 1969), Klaus Beyenbach and colleagues studied the role of proximal tubular salt and water secretion in fish renal function at the MDIBL during the 1980s and early1990s. The initial studies demonstrated that the proximal tubule of the shark, Squalus acanthias, secreted $\mathrm{Cl}^{-}$into the lumen of the perfused tubule, against the electrochemical gradient, with basolateral uptake possibly via a furosemide-sensitive $\mathrm{NaCl}$ cotransport carrier (Beyenbach and Fromter, 1985). A subsequent study showed that the shark tubule could produce a furosemidesensitive, net secretion of fluid that was slightly hypertonic to the peritubular fluid, but contained primarily $\mathrm{Na}^{+}$and $\mathrm{Cl}^{-}$, at concentrations equivalent to the peritubular fluid. They proposed that the driving force for fluid secretion in the shark proximal tubule was basolateral entry of $\mathrm{NaCl}$ via a furosemide-sensitive cotransporter, followed by apical extrusion of $\mathrm{Cl}^{-}$via a $\mathrm{Cl}^{-}$channel, with $\mathrm{Na}^{+}$following via a paracellular pathway (Sawyer and Beyenbach, 1985). Interestingly, similar studies on the perfused flounder tubule found that the secreted fluid contained significantly more $\mathrm{Cl}^{-}$than the peritubular bath, but that the $\mathrm{Mg}^{2+}$ and $\mathrm{SO}_{4}^{2-}$ concentrations were 10-fold enriched, suggesting these divalent ions as the driving force (Beyenbach et al., 1986). This hypothesis was confirmed in an accompanying study that showed that fluid secretion was depend- 
ent upon both peritubular $\mathrm{Mg}^{2+}$ and $\mathrm{Na}^{+}$, suggesting dual driving forces: $\mathrm{MgCl}_{2}$ and $\mathrm{NaCl}$ secretion (Cliff et al., 1986). These studies, and many others on various aspects of proximal tubular secretion at the MDIBL and elsewhere, have been reviewed relatively recently by Beyenbach (2004), and Grantham and Wallace have reviewed the importance of proximal tubular secretion in mammalian renal function (Grantham and Wallace, 2002). Both conclude that, in addition to the secretion of unwanted toxins, proximal secretion of ions and water plays a significant role in total renal ion and water balance throughout the vertebrates, including mammals. In fact, Beyenbach calculated that proximal tubular fluid secretion may approach $300 \%$ of the glomerular filtration rate in marine fishes and 5\% in humans (Beyenbach, 2004), which may become critically important during acute renal failure (Grantham and Wallace, 2002).

\section{THE NACL COTRANSPORTERS ${ }^{5}$ $\mathrm{Na}^{+}+\mathrm{Cl}^{-}$COTRANSPORT}

A electroneutral $\mathrm{NaCl}$ cotransport system was first suggested by Jared Diamond ${ }^{6}$, who worked on the freshwater fish (roach) gallbladder at Cambridge University. He found that both $\mathrm{Na}^{+}$and $\mathrm{Cl}^{-}$were actively transported, but the low transepithelial electrical potentials indicated that their transport was "on the same carrier molecules (Diamond, 1962)." We now know, however, that the transport of $\mathrm{NaCl}$ across the vertebrate gallbladder is not chemically coupled, but rather via parallel $\mathrm{Na}^{+} / \mathrm{H}^{+}$and $\mathrm{Cl}^{-} / \mathrm{HCO}_{3}^{-}$exchangers (Reuss et al., 1991). Larry Renfro came to the MDIBL in the early 1970s, as Bodil Schmidt-Nielsen's ${ }^{7}$ postdoc and studied $\mathrm{NaCl}$ transport across the flounder urinary bladder, which, unlike the toad bladder, is a mesodermal derivative of the mesonephric ducts, and therefore can be treated as an extension of the distal kidney. Renfro found that the perfused bladder reabsorbed $\mathrm{Na}^{+}$and $\mathrm{Cl}^{-}$at the same rate, and the transepithelial potential was $<5 \mathrm{mV}$, lumen fluids positive. Moreover, the transepithelial fluxes of both ion were relatively unaffected by clamping the voltage across the bladder at zero or $\pm 50 \mathrm{mV}$. Both ouabain and furosemide inhibited $\mathrm{Na}^{+}, \mathrm{Cl}^{-}$, and water movement across the bladder. Renfro concluded that "in addition to the fact that both $\mathrm{Na}^{+}$and $\mathrm{Cl}^{-}$appear to be actively transported, their movements through the epithelial membranes indicated that they are linked (Renfro, 1975).” David Dawson came to the MDIBL in the summer of 1979 to study this system further, using isolated sheets of bladder in an Using chamber. He confirmed that the short-circuit current $\left(I_{\mathrm{sc}}\right)$ and net uptakes of $\mathrm{Na}^{+}$and $\mathrm{Cl}^{-}$were equivalent, and inhibited by ouabain (Dawson and Andrew, 1979). John Stokes came the next summer to attempt to differentiate between three possible mechanisms for this electroneutral $\mathrm{NaCl}$ absorption by the flounder urinary bladder: $\mathrm{Na}^{+}$/ $\mathrm{K}^{+} / 2 \mathrm{Cl}^{-}$cotransport, parallel $\mathrm{Na}^{+} / \mathrm{H}^{+}$and $\mathrm{Cl}^{-} / \mathrm{OH}^{-}$exchanges, and simple $\mathrm{Na}^{+}+\mathrm{Cl}^{-}$cotransport. He confirmed that the uptakes of either $\mathrm{Na}^{+}$or $\mathrm{Cl}^{-}$were dependent upon the other ion in the bathing

${ }^{5}$ Reviews of $\mathrm{NaCl}$ cotransporters include Frizzell et al. (1979a), Hebert and Gullans (1995), Kaplan et al. (1996), and Hebert et al. (2004).

${ }^{6}$ Diamond switched from physiology to ecology and evolutionary biology decades ago and is known currently as a best-selling author of socio-economic books, such as "Collapse" (Viking Press, 2004).

${ }^{7}$ Bodil Schmidt-Nielsen began spending summers at MDIBL in 1952, invited by Homer Smith. She had a long, distinguished career, moved to MDIBL on a yearround basis in 1970, and retired in 1986 . solution, but not on the presence of $\mathrm{K}^{+}$. The $I_{\text {sc }}$ was unaffected by amiloride, DIDS or acetazolamide, suggesting that parallel exchangers were unlikely. Ouabain inhibited the uptake much more than furosemide or bumetanide did, but hydrochlorothiazide inhibited the $I_{\text {sc }}$ even more significantly, in a concentration-dependent manner, and completely inhibited the uptake of $\mathrm{Na}^{+}$. Stokes concluded: "The mechanism of $\mathrm{NaCl}$ absorption in this tissue appears to be a simple interdependent process. Its inhibition by thiazide diuretics appears to be a unique feature". Stokes proposed that the flounder bladder "may be a model for $\mathrm{NaCl}$ absorption in the distal renal tubule (Stokes, 1984)." Subsequently, Steve Hebert's group used cDNA from flounder bladders they had harvested at the MDIBL (and at the MBL, Woods Hole) to clone and sequence this thiazidesensitive $\mathrm{NaCl}$ cotransporter (Gamba et al., 1993), which is now termed $\mathrm{NaCl}$ cotransporter (NCC), and is a product of the SLC12 gene family (SLC12A3) (Hebert et al., 2004). Subsequent studies, however, by Renfro on the winter flounder urinary bladder (Renfro, 1977) suggested that approximately $25 \%$ of the $\mathrm{NaCl}$ uptake was via $\mathrm{Na}^{+} / \mathrm{H}^{+}$and $\mathrm{Cl}^{-} / \mathrm{HCO}_{3}^{-}$exchangers, and this was confirmed in another flounder species (Demarest, 1984). More recently, studies using urinary bladders from freshwater, salmonid species have corroborated this suggestion that luminal $\mathrm{Na}^{+} / \mathrm{H}^{+}$and $\mathrm{Cl}^{-} / \mathrm{HCO}_{3}^{-}$ exchangers, rather than $\mathrm{Na}^{+}+\mathrm{Cl}^{-}$cotransport, accounts for $\mathrm{NaCl}$ uptake (Marshall, 1986; Burgess et al., 2000). Thus, it appears that the urinary bladder of fishes extracts $\mathrm{NaCl}$ from the lumen via both $\mathrm{NCC}$ and parallel $\mathrm{Na}^{+} / \mathrm{H}^{+}$and $\mathrm{Cl}^{-} / \mathrm{HCO}_{3}^{-}$exchangers.

\section{$\mathrm{Na}^{+}+\mathrm{K}^{+}+2 \mathrm{Cl}-$ COTRANSPORT}

Working with Bill Kinter at the MDIBL in the mid-1970s, Michael Field and collaborators showed that the flounder intestine absorbed both $\mathrm{Na}^{+}$and $\mathrm{Cl}^{-}$, but that the uptake of $\mathrm{Cl}^{-}$was abolished by replacing the mucosal $\mathrm{Na}^{+}$with choline, as was the uptake of $\mathrm{Na}^{+}$when $\mathrm{Cl}^{-}$was replaced by $\mathrm{SO}_{4}^{2-}$. Moreover, $\mathrm{Cl}^{-}$uptake was inhibited by the addition of ouabain. The authors proposed that the mucosal uptake of $\mathrm{NaCl}$ was coupled 1:1 (Field et al., 1978). Field invited Ray Frizzell to the MDIBL in the summer of 1977 to work on the flounder intestine, and they confirmed that mucosal $\mathrm{NaCl}$ uptake was dependent upon both $\mathrm{Na}^{+}$and $\mathrm{Cl}^{-}$in the luminal solution and inhibited by furosemide. Ionic replacement and furosemide inhibition had equivalent effects on both ion fluxes, confirming that the $\mathrm{NaCl}$ coupling was probably 1:1 (Frizzell et al., 1979b). These, and many other studies on a variety of $\mathrm{NaCl}$ absorbing tissues in the vertebrates (e.g., mammalian ileum, gallbladder, and colon; amphibian proximal renal tubule, intestine, and skin), were reviewed by Frizzell (1979a). As the authors pointed out, this $\mathrm{NaCl}$ coupled uptake is characteristic of "leaky epithelia," which possess relatively low-resistance, paracellular pathways, and was driven by $\mathrm{Na}^{+} / \mathrm{K}^{+}$exchange on the serosal membrane, which maintained intracellular $\mathrm{Na}^{+}$concentrations low. They also suggested that the flounder intestine might be a good model for the thick ascending limb in the mammalian kidney (Frizzell et al., 1981).

The role of mucosal $\mathrm{K}^{+}$in this mucosal, furosemide-sensitive $\mathrm{NaCl}$ uptake by the flounder intestine was not appreciated until Field's group (Musch et al., 1982) demonstrated that this uptake by the flounder intestine was dependent upon mucosal $\mathrm{K}^{+}$. In addition, $\mathrm{K}^{+}$uptake (measured by ${ }^{86}$ Rubidium) was dependent upon both $\mathrm{Na}^{+}$and $\mathrm{Cl}^{-}$in the mucosal solution, and was inhibited by furosemide. They proposed that the $\mathrm{NaCl}$ uptake cotransporter on the flounder intestine mucosal membrane was 
actually a $\mathrm{Na}^{+}+\mathrm{K}^{+}+\mathrm{Cl}^{-}$carrier (actually $\mathrm{Na}^{+}+\mathrm{K}^{+}+2 \mathrm{Cl}^{-}$), similar to that being described for the erythrocyte (Haas et al., 1982), the MDCK cell line (McRoberts et al., 1982), and the ascending limb of the loop of Henle (Greger and Schlatter, 1981). This carrier has now been localized to the luminal membrane in the intestine of various species (Suvitayavat et al., 1994; Marshall et al., 2002; Lorin-Nebel et al., 2006; Cutler and Cramb, 2008), and Biff Forbush's group at the MDIBL has cloned an NKCC2 and localized the transcript to intestinal tissue in the killifish (Djurisic et al., 2003). Presumably, it is a product of the SLC12 gene family (SLC12A1) (Hebert et al., 2004). Interestingly, mammalian intestinal $\mathrm{NaCl}$ uptake is thought to be via parallel $\mathrm{Na}^{+} / \mathrm{H}^{+}(\mathrm{NHE} 2$ and $\mathrm{NHE} 3)$ and $\mathrm{Cl}^{-} / \mathrm{HCO}_{3}^{-}$(AE4, DRA, and PAT1) exchangers (Venkatasubramanian et al., 2010) ${ }^{8}$. In addition, more recent evidence suggests that some $\mathrm{Cl}^{-}$ uptake by the fish intestine is, in fact, via $\mathrm{Cl}^{-} / \mathrm{HCO}_{3}^{-}$exchange (Marshall and Grosell, 2006; Grosell and Taylor, 2007). Indeed, the $\mathrm{Cl}^{-} / \mathrm{HCO}_{3}^{-}$ exchanger provides $\mathrm{HCO}_{3}^{-}$for the precipitation of intestinal $\mathrm{Ca}^{2+}$ and may actually play an important role in the ocean's inorganic carbon cycle (Tsui et al., 2009). In addition, basolateral and apical $\mathrm{H}^{+}$-pumps, as well as a basolateral $\mathrm{Na}^{+} / \mathrm{H}^{+}$exchanger, $\mathrm{K}^{+}+\mathrm{Cl}^{-}$cotransporter, $\mathrm{Cl}^{-}$channel, and $\mathrm{a} \mathrm{Na}+\mathrm{HCO}_{3}$ cotransporter (NBC1) have been described for fish intestine (Halm et al., 1985; Loretz and Fourtner, 1988; Grosell et al., 2009; Taylor et al., 2010) (Figure 2).

\section{THE SHARK RECTAL GLAND ${ }^{9}$}

As mentioned above, Homer Smith determined that elasmobranchs must have extrarenal mechanisms for salt extrusion, and suggested that possibly the gills were the site of this transport.

${ }^{8} \mathrm{NaCl}$ secretion in the mammalian intestine is via NKCC1 and CFTR (Venkatasubramanian et al., 2010).

${ }^{9}$ For reviews of rectal gland physiology, see Greger et al. (1986), Silva et al. (1990b, 1996, 1997), Riordan et al. (1994), and Forrest (1996).
Wendell Burger's work at the MDIBL in the early 1960s provided the first suggestion that the rectal gland was, in fact, the site of extrarenal salt secretion. His initial study demonstrated that the rectal gland fluid was approximately isotonic to the plasma, but contained nearly twice as much $\mathrm{NaCl}$ (and even more than seawater!) and virtually no urea (Burger and Hess, 1960). Since extremely high concentrations of $\mathrm{Na}^{+}, \mathrm{K}^{+}$-ATPase had been found in the rectal gland of Squalus acanthias (Bonting, 1966) Lowell Hokin, responding to an invitation from Frank Epstein (see below) came to the MDIBL in the summers of 1971-1972 to harvest as many shark rectal glands as possible. The result was the most complete purification (66-95\%, depending on the calculated molecular weight of the putative protein) of $\mathrm{Na}^{+}, \mathrm{K}^{+}$-ATPase to date. Within 2 years, Hokin and Shirley Hilden had produced vesicles from the shark rectal gland containing $>90 \%$ pure $\mathrm{Na}^{+}$, $\mathrm{K}^{+}$-ATPase, which could mediate the 3:2 exchange of $\mathrm{K}^{+}$for $\mathrm{Na}^{+}$ (Hilden and Hokin, 1975).

Study of the actual transport mechanisms that produce the secretion of the rectal gland was initiated when John Hayslett's group came to the MDIBL in the summer of 1973 and perfected the first perfusion of the isolated gland from Squalus acanthias (Hayslett et al., 1974). They demonstrated that the perfused gland could secrete fluid at rates comparable to the intact gland, and that the glandular fluid contained about $50 \%$ more $\mathrm{Na}^{+}$than the perfusion fluid. Measurement of the electrical potential between the secreted fluid and the perfusate showed that both $\mathrm{Na}^{+}$and $\mathrm{Cl}^{-}$were secreted against their respective electrochemical gradients, but the gradient for $\mathrm{Cl}^{-}$was more than twice that for $\mathrm{Na}^{+}$(Hayslett et al., 1974). In a subsequent study, Hayslett's group demonstrated more clearly that $\mathrm{Cl}^{-}$was secreted against a much steeper electrochemical gradient than $\mathrm{Na}^{+}$and that $\mathrm{Na}^{+}$secretion was dependent upon perfusate $\mathrm{Cl}^{-}$(Siegel et al., 1976).

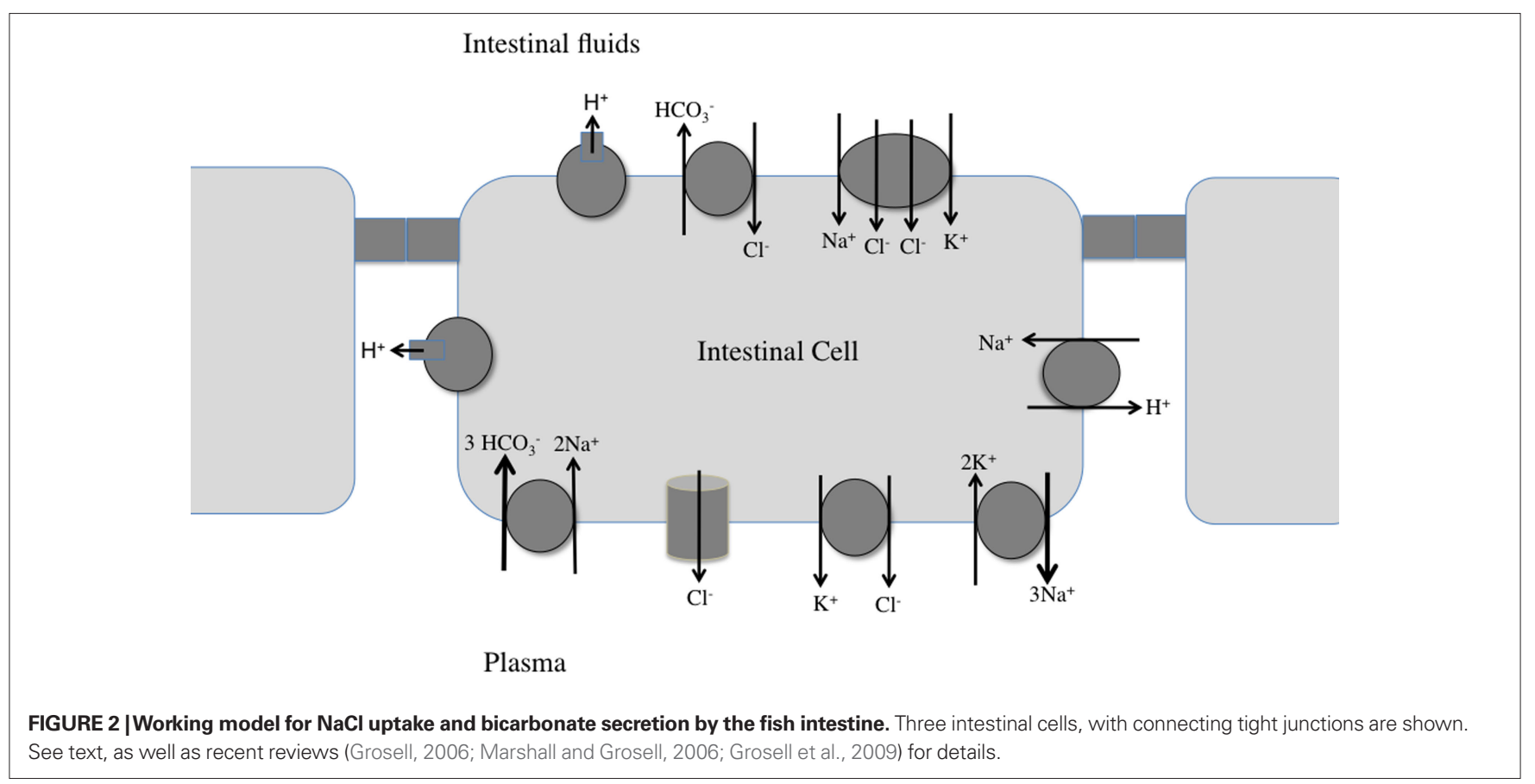


Since these initial studies, this perfused gland preparation has been used (largely by Frank Epstein and colleagues at the MDIBL) to dissect both the transport steps and control mechanisms for $\mathrm{NaCl}$ secretion by the shark rectal gland. In the early studies of the perfused rectal gland, the perfusion rate often declined over time, so that some inhibitor studies were not possible. Working in Epstein's lab in the summer of 1976, Jeff Stoff discovered that the gland could be stimulated to maintain nearly constant perfusion rates for up to $60 \mathrm{~min}$ if theophylline and dibutyryl cyclic AMP were applied, suggesting that intracellular cyclic AMP levels was an important mediator of secretion (Silva et al., 1977b). The group also demonstrated that ouabain, furosemide, and substitution of perfusate $\mathrm{Na}^{+}$with choline inhibited gland $\mathrm{Cl}^{-}$secretion significantly. Based upon these data, this group proposed a model for transepithelial transport mediated by a basolateral, linked $\mathrm{NaCl}$ carrier that was driven by the inward electrochemical gradient for $\mathrm{Na}^{+}$, which in turn was produced by and adjacent, basolateral $\mathrm{Na}^{+}, \mathrm{K}^{+}$-ATPase. Intracellular $\mathrm{Cl}^{-}$was thought to exit the apical membrane by some unknown $\mathrm{Cl}^{-}$carrier or channel, and $\mathrm{Na}^{+}$ moved through the paracellular pathway down its electrochemical gradient (Silva et al., 1977b). Along with a companion paper outlining a similar hypothesis for salt secretion by the teleost gill (Silva et al., 1977a, and see below), this was one of the first proposals for a $\mathrm{NaCl}$ coupled transporter driving salt secretion across an epithelium (Frizzell et al., 1979a). Work on the spiny dogfish rectal gland also generated the first antibodies for the $\mathrm{Na}^{+}+\mathrm{K}^{+}+\mathrm{Cl}^{-}$cotransporter (Lytle et al., 1992), and the first cloning and functional expression of a bumetanide-sensitive $\mathrm{Na}^{+}+\mathrm{K}^{+}+\mathrm{Cl}^{-}$cotransporter (Xu et al., 1994) by Biff Forbush's group at the MDIBL in 1992-1994. It is now known that this rectal gland $\mathrm{Na}^{+}+\mathrm{K}^{++}+2 \mathrm{Cl}^{-}$cotransporter is NKCC1, a product of the SLC12 gene family (SLC12A2; Hebert et al., 2004). The apical $\mathrm{Cl}^{-}$channel of the rectal gland displayed many of the electrical characteristics of the cystic fibrosus transmembrane conductance regulator (CFTR) when expressed in Xenopus oocytes by Mike Field's group (Sullivan et al., 1991) (not working at the MDIBL), and shark CFTR was cloned independently by two nonMDIBL groups (Grzelczak et al., 1990; Marshall et al., 1991). More recently, John Forrest's group at the MDIBL has cloned a $\mathrm{K}^{+}$channel from the rectal gland, which presumably mediates basolateral cycling of $\mathrm{K}^{+}$(Waldegger et al., 1999).

Subsequent studies at the MDIBL have produced a relatively good understanding of the myriad of physiological controls of the secretion by the rectal gland, and, by inference in some cases, putative controls of both the basolateral NKCC1 and the apical CFTR (e.g., Riordan et al., 1994; Hanrahan et al., 1996). Vasoactive intestinal peptide (VIP) is a potent stimulant of rectal gland secretion (Stoff et al., 1979), as is atrial natriuretic peptide, by stimulation of VIP release (Silva et al., 1987). Subsequent work with cultured rectal gland tissue sheets demonstrated that ANP also can stimulate the $I_{\text {sc }}$ across this tissue directly (Karnaky et al., 1991). Other studies have demonstrated that the endogenous natriuretic peptide is actually C-type natriuretic peptide in elasmobranchs (Schofield et al., 1991), and the appropriate receptor (NPR-B) was cloned from rectal gland tissue by John Forrest's group (Aller et al., 1999). Forrest's group has also cloned the VIP receptor from the rectal gland (Bewley et al., 2006). Neuropeptide Y inhibits secretion by the perfused gland (Silva et al., 1993), as does somatostatin (Silva et al., 1985). Bombesin also inhibits gland secretion, but via the release of somatostatin
(Silva et al., 1990a). Adenosine inhibits gland secretion at low concentrations $\left(<10^{-7} \mathrm{M}\right)$ but stimulates secretion at concentrations greater than $10^{-6} \mathrm{M}$ (Kelley et al., 1990). In addition to exogenous and endogenous signals that may stimulate or inhibit salt transport across the glandular epithelium, it appears that the gland also may be regulated by alterations in perfusion via the posterior mesenteric artery since the anterior mesenteric artery responds to both putative constrictory (acetylcholine and endothelin) and dilatory (C-type natriuretic peptide and prostanoids) signaling agents (Evans, 2001). In addition, the rectal gland has a circumferential ring of smooth muscle, and so the gland itself responds to this same suite of putative vasoactive substances (Evans and Piermarini, 2001). Somewhat surprisingly, it appears that the rectal gland responds to plasma volume rather than salt concentration (Solomon et al., 1985).

\section{MARINE TELEOST GILL SALT SECRETION ${ }^{10}$}

As mentioned in Section "Introduction," Homer Smith proposed that the gills were the likely site of net salt secretion in marine teleosts, since the kidney was unable to produce a urine that was hypertonic to the fish's plasma (Smith, 1930). This proposition was supported by the very careful experiments by Ancel Keys in August Krogh's laboratory in Copenhagen that demonstrated that the perfused eel gill could secreted $\mathrm{Cl}$ against the chemical gradient, probably the first description of active transport across an epithelium (Keys, 1931). Keys also described what he termed "chloride-secreting cells" in the gill epithelium of the eel (Keys and Willmer, 1932), which he proposed could be the site of this active salt transport. Subsequent studies demonstrated that this cell displayed morphological characteristics of other transporting cells (e.g., elaboration of the basolateral membrane and numerous mitochondria ${ }^{11}$ (Philpott, 1965), and expressed high concentration of $\mathrm{Na}^{+}, \mathrm{K}^{+}$-activated ATPase (Kamiya, 1972; Sargent et al., 1975). Previously, Frank Epstein's lab at the MDIBL had demonstrated relatively high concentrations of $\mathrm{Na}^{+}, \mathrm{K}^{+}$-ATPase in the gill tissue of marine teleosts (Jampol and Epstein, 1970). Two early studies presented evidence that the $\mathrm{Na}^{+} / \mathrm{K}^{+}$exchange might be apical (seawater $\mathrm{K}^{+}$for intracellular $\mathrm{Na}^{+}$; (Maetz, 1969; Evans and Cooper, 1976), but Karl Karnaky went to do a postdoc with Bill Kinter at the MDIBL in 1972 and demonstrated conclusively that tritiated ouabain (binding to $\mathrm{Na}^{+}, \mathrm{K}^{+}$-activated ATPase) was on the basolateral membrane of the chloride cell in the killifish gill (Karnaky et al., 1976) ${ }^{12}$. Reasoning that basolateral $\mathrm{Na}^{+}, \mathrm{K}^{+}$-ATPase should be inhibited by injected ouabain, Patricio Silva in Epstein's group discovered that such an injection into the seawater acclimated eel inhibited both $\mathrm{Na}^{+}$and $\mathrm{Cl}^{-}$efflux, with little effect on the efflux of tritiated water (suggesting that a change in branchial blood flow was not the cause of the ionic efflux declines) (Silva et al., 1977a). They suggested that such functional coupling of $\mathrm{Na}^{+}$and $\mathrm{Cl}^{-}$efflux was best explained by the model that they proposed at the same time

\footnotetext{
${ }^{10}$ For a more complete discussion of gill salt transport, see Evans et al. (2005). ${ }^{11}$ These cells are now commonly termed mitochondrion-rich cells.

${ }^{12}$ It is important to note that it was during the mid-70s that the mechanisms for fish intestinal $\mathrm{NaCl}$ absorption, gill salt secretion, and rectal gland salt secretion were being investigated in adjoining labs at the MDIBL. Karnaky has presented an interesting, first-person account of the interactions between the Kinter, Field, and Epstein labs during this time period (Karnaky, 2008).
} 
for salt secretion by the shark rectal gland (Silva et al., 1977b). This model was confirmed by Karl Karnaky, using the isolated killifish opercular membrane, which he showed had a high concentration of chloride cells (Karnaky and Kinter, 1977). Karnaky and colleagues at the MDIBL found that this tissue could be mounted in a small-aperture, Ussing chamber which allowed measurement of ionic fluxes under short-circuited conditions. They showed clearly that the $I_{\text {sc }}$ was accounted for by the net efflux of $\mathrm{Cl}^{-}$, which was inhibited by basolateral addition of either ouabain or furosemide. There was no net efflux of $\mathrm{Na}^{+}$under the short-circuited conditions (Degnan et al., 1977), indicating that $\mathrm{Na}^{+}$movement was passive, through the tight junctions between the epithelial cells (Figure 3). More recently, a potassium channel has been localized in MRC, presumably the site of recycling of $\mathrm{K}^{+}$(Suzuki et al., 1999).

Karnaky's group also demonstrated that the $I_{\text {sc }}$ across the killifish opercular membrane was inhibited by epinephrine (Degnan et al., 1977), and subsequent studies found that this inhibition was mediated by $\alpha$-adrenergic receptors, while stimulation of $\beta$-adrenergic receptors resulted in an increase in the $I_{\text {sc }}$ (Mendelsohn et al., 1981). A variety of signaling agents have been shown to modulate teleost gill salt extrusion (for reviews see McCormick, 2001; Evans, 2002; Evans et al., 2005), including endothelin, which our work at the MDIBL has shown, inhibits $I_{\mathrm{sc}}$ across the opercular membrane via an axis that includes nitric oxide, superoxide, and a prostaglandin (Evans et al., 2004).

\section{EVOLUTIONARY ORIGIN OF NaCI UPTAKE MECHANISMS IN FRESHWATER FISHES ${ }^{13}$}

August Krogh was a Danish contemporary of Smith and Marshall, and the postdoctoral advisor of Ancel Keys. His notable contribution to the study of fish osmoregulation was the hypothesis that

${ }^{13}$ For a more complete discussion of the mechanisms of salt uptake by the freshwater fish gill, see Evans and Claiborne (2009), Hwang (2009), and Evans (2010). freshwater fishes extract needed $\mathrm{NaCl}$ from the environmental via parallel $\mathrm{Na}^{+} / \mathrm{NH}_{4}^{+}$and $\mathrm{Cl}^{-} / \mathrm{HCO}_{3}^{-}$exchangers (Krogh, 1937, 1938). He proposed these ionic exchanges because he demonstrated that non-feeding catfishes, sticklebacks, perch, and trout could reduce the $\mathrm{Cl}^{-}$concentration of tank water surrounding the head end of the fish in divided chamber experiments. Importantly, he found that the $\mathrm{Cl}^{-}$uptake was independent of the cation $\left(\mathrm{Na}^{+}, \mathrm{K}^{+}, \mathrm{NH}_{4}^{+}\right.$, and $\left.\mathrm{Ca}^{2+}\right)$, and the uptake of $\mathrm{Na}^{+}$was independent of the anion $\left(\mathrm{Cl}^{-}\right.$, $\mathrm{Br}^{-}, \mathrm{HCO}_{3}^{-}$, and $\mathrm{NO}_{3}^{-}$). In fact, he found similar results with freshwater annelids, mollusks, and crustacea, and proposed that these ionic exchange mechanisms were a general phenomenon in hyperregulating, freshwater organisms (Krogh, 1939). Data published in the last two decades suggests that the $\mathrm{Na}^{+}$uptake actually is coupled to $\mathrm{H}$ loss, either by an apical $\mathrm{Na}^{+} / \mathrm{H}^{+}$exchanger or via an apical $\mathrm{Na}^{+}$ channel which moves $\mathrm{Na}^{+}$inward down an electrochemical gradient produced by an apical proton pump (V-H'-ATPase) (e.g., Hwang, 2009). Chloride uptake is thought to be either via Krogh's $\mathrm{Cl}^{-} / \mathrm{HCO}_{3}^{-}$ exchanger (SLC26; Perry et al., 2009) or possibly via an apical NCC coupled to a basolateral CIC-type Cl channel (Hwang, 2009; Tang et al., 2010). Ammonia excretion is now thought to be via diffusion of either $\mathrm{NH}_{3}$ or $\mathrm{NH}_{4}^{+}$(Wilkie, 2002), or via the newly described, Rh glycoproteins (Weihrauch et al., 2009; Wright and Wood, 2009; $\mathrm{Wu}$ et al., 2010). Also, it is now generally agreed that the uptake of $\mathrm{Na}^{+}$vs. $\mathrm{Cl}^{-}$is mediated by channels and carriers on different, mitochondrion-rich cells (e.g., Hwang and Lee, 2007) (Figure 4).

Regardless of the actual mechanisms involved, it is apparent that the uptake of needed $\mathrm{NaCl}$ by freshwater fishes is coupled to the equally-important extrusion of acid-base equivalents ${ }^{14}$ and nitrogen wastes, a proposition that was first described 35 years ago (Evans, 1975). If this is the case, one might propose that

${ }^{14}$ For a more complete discussion of acid-base regulation in fishes, see Claiborne et al. (2002).

Seawater or Rectal gland secretory fluid

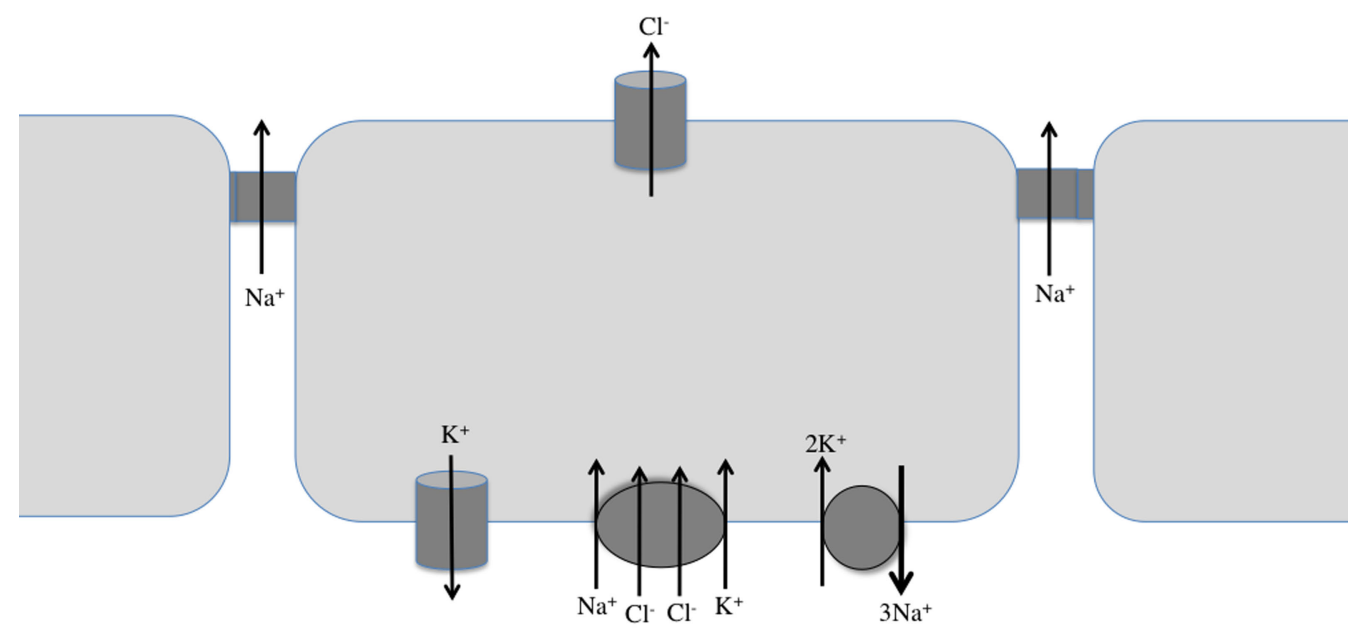

Plasma

FIGURE 3 |Working model for $\mathrm{NaCl}$ secretion by the shark rectal gland and marine teleost gill epithelium. Three epithelial cells, with connecting tight junctions are shown. See text for details. 


\section{Fresh water}

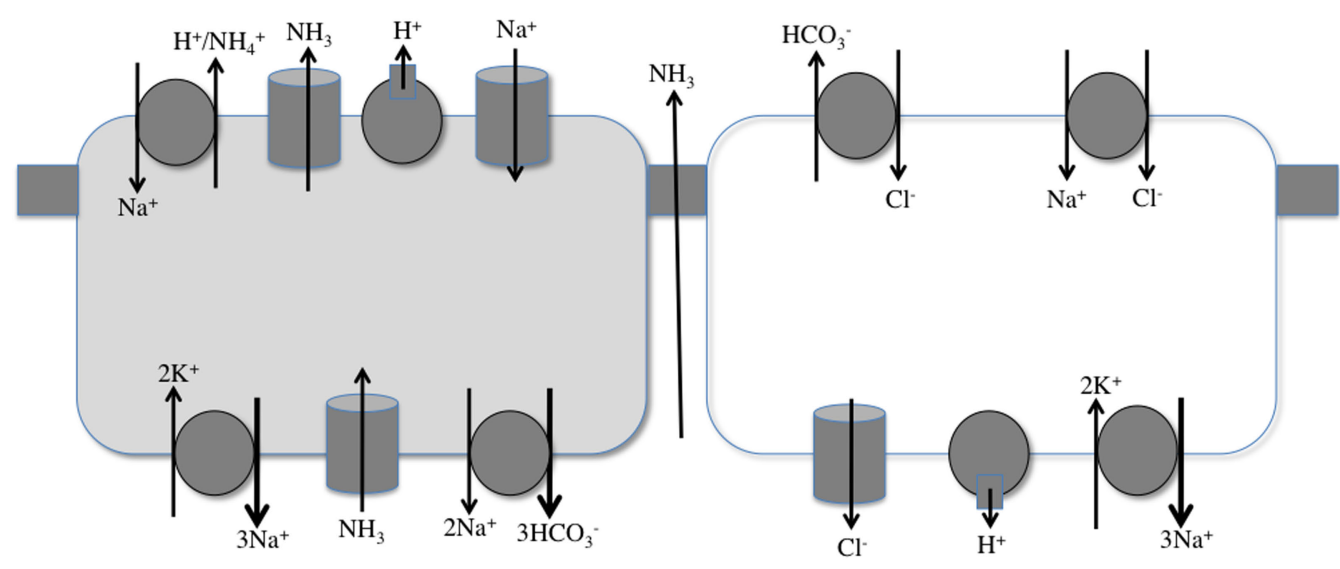

Plasma

FIGURE 4 |Working model for $\mathrm{NaCl}$ uptake and acid/base or ammonia secretion by the teleost gill epithelium. Two epithelial cells, with connecting tight junctions are shown. The distribution of the transport proteins in specific cells may vary with fish species. See text and Evans (2010) for details.

they would be present in marine fish species, driven by needs for acid-base regulation and/or nitrogen waste excretion, rather than ion uptake. Our initial studies at the University of Miami demonstrated that $\mathrm{Na}^{+}$uptake by a seawater acclimated, sailfin molly was saturable (and. therefore, presumably not via simple diffusion) and inhibited by external amiloride (which was thought to inhibit $\mathrm{Na}^{+} / \mathrm{H}^{+}$exchange, Kirschner et al., 1973). In addition, $\mathrm{Na}^{+}$uptake by four species of marine teleosts could be inhibited by the addition of $\mathrm{NH}_{4}^{+}$to the medium (Evans, 1977). In order to extend these data to elasmobranchs, we came to the MDIBL in the summer of 1978. Using the little skate, we found that $\mathrm{H}^{+}$efflux (but not ammonia efflux) was dependent upon external $\mathrm{Na}^{+}$and inhibited by amiloride, suggesting that $\mathrm{H}^{+}$excretion by the gill epithelium of this marine elasmobranch was via a $\mathrm{Na}^{+} / \mathrm{H}^{+}$exchanger (Evans et al., 1979). The importance of such exchanges in acid-base regulation in at least teleosts was shown clearly by J. B. Claiborne and colleagues, working at the MDIBL, who demonstrated that recovery from induced acidosis in the longhorn sculpin was inhibited by low external $\mathrm{Na}^{+}$concentrations (20-30 mM) or by external amiloride [or the more $\mathrm{Na} / \mathrm{H}$ specific 5-N,N-hexamethylene-amiloride (HMA)] (Claiborne and Evans, 1988). These physiological data were corroborated by subsequent molecular data showing immunolocalization of $\mathrm{Na}^{+} / \mathrm{H}^{+}$exchanger isoforms (NHEs), and $\mathrm{V}-\mathrm{H}^{+}$-ATPase, in the gill epithelium of the sculpin in seawater (Claiborne et al., 1999; Catches et al., 2006), and this gill localization of NHEs has now been extended to the little skate (Choe et al., 2002), spiny dogfish (Tresguerres et al., 2005; Choe et al., 2007), and killifish (Claiborne et al., 1999; Choe et al., 2002; Edwards et al., 2010) at the MDIBL. V-H - -ATPase and a $\mathrm{Cl}^{-} / \mathrm{HCO}_{3}^{-}$exchanger (pendrin) have also been immunolocalized in the gill epithelium of the Atlantic stingray in seawater (Piermarini and Evans, 2001; Piermarini et al., 2002).
If, as these data suggest, the gill epithelium of marine teleosts and elasmobranchs expresses ionic transporters and channels (e.g., NHEs, $\mathrm{V}-\mathrm{H}^{+}$-ATPase, and $\mathrm{Cl}^{-} / \mathrm{HCO}_{3}^{-}$exchanger) that function in acid-base regulation, but also can function in $\mathrm{NaCl}$ uptake, when did these exchangers evolve in the vertebrates (marine ancestors vs. freshwater ancestors?). Working at the MDIBL in the summer of 1983, we found that acid excretion from the Atlantic hagfish (a member of the most primitive vertebrate group, the agnatha) is inhibited by removal of external $\mathrm{Na}^{+}$, and the excretion of base was inhibited by removal of external $\mathrm{Cl}^{-}$, suggesting that $\mathrm{Na}^{+} / \mathrm{H}^{+}$ and $\mathrm{Cl}^{-} / \mathrm{HCO}_{3}^{-}$exchangers were present in the most primitive vertebrates, before the evolution of either the elasmobranchs or teleosts. This is supported by the more recent work at the MDIBL that has immunolocalized an NHE to gill tissue from the Atlantic hagfish (Choe et al., 2002) and, from the Bamfied Marine lab (Canada), NHE and V-H+ $\mathrm{H}^{+}$-ATPase from the Pacific hagfish (Tresguerres et al., 2006). Moreover, acidosis in the Pacific species is correlated with an increase in the NHE levels in the gill epithelium (Parks et al., 2007). An NHE also has been localized (by rtPCR) to the gill epithelium of the sea lamprey at the MDIBL, another member of the agnatha (Fortier et al., 2008). Thus, it seems clear that the gill transport mechanisms that provide necessary $\mathrm{NaCl}$ uptake in freshwater fishes actually evolved in marine ancestors for acid-base regulation. If this is the case, one might ask why all fishes (including the primitive hagfishes) are not euryhaline? There is no clear answer to this question, but one might propose that the kinetics of ionic uptake (mediated by a carrier with a finite affinity and number) vs. ionic loss (via diffusion and renal excretion) are not in balance in the more stenohaline species (Evans, 1984). The kinetic analyses of uptake vs. loss in different salinities necessary to test this hypothesis have not been published. Another limiting factor may be the ability to turn off the gill $\mathrm{NaCl}$ excretory mechanisms necessary for osmoregulation in seawater. This seems to be the case with the 
partially euryhaline longhorn sculpin. Working at the MDIBL Kelly Hyndman has shown that this species is unable to downregulate gill levels of mRNA or protein for $\mathrm{Na}^{+}, \mathrm{K}^{+}$-ATPase, NKCC, or CFTR when it is in 20\% seawater (Hyndman and Evans, 2009).

\section{CONCLUSIONS}

The foregoing outlines over 80 years of research at the MDIBL that has formed the basis for current models for many of the strategies of fish osmoregulation, as well as mechanisms of ion transport across epithelial membranes in general. It is clear that the synergy that characterizes research at the MDIBL (and, indeed, other similar

\section{REFERENCES}

Aller, S. G., Lombardo, I. D., Bhanot, S., and Forrest, J. N. Jr. (1999). Cloning, characterization, and functional expression of a CNP receptor regulating CFTR in the shark rectal gland. Am. J. Physiol. 276, C442-C449.

Bewley, M. S., Pena, J. T., Plesch, F. N., Decker, S. E., Weber, G. J., and Forrest, J. N. Jr. (2006). Shark rectal gland vasoactive intestinal peptide receptor: cloning, functional expression, and regulation of CFTR chloride channels. Am. J. Physiol. 291, R1157-R1164.

Beyenbach, K. W. (2004). Kidneys sans glomeruli.Am. J. Physiol. Renal Physiol. 286, F811-F827.

Beyenbach, K. W., and Fromter, E. (1985). Electrophysiological evidence for $\mathrm{Cl}$ secretion in shark renal proximal tubules. Am. J. Physiol. 248, F282-F295.

Beyenbach, K. W., Petzel, D. H., and Cliff, W. H. (1986). Renal proximal tubule of flounder. I. Physiological properties. Am. J. Physiol. 250, R608-R615.

Bonting, S. L. (1966). Studies on sodiumpotassium-activated adenosinetriphosphatase. XV. The rectal gland of the elasmobranchs. Comp. Biochem. Physiol. 17, 953-966.

Burg, M., Grrantham, J., Abramov, M., and Orloff, J. (1966). Preparation and study of fragments of single rabbit nephrons. Am. J. Physiol. Renal. 210, 1293-1298.

Burg, M. B., and Weller, P. F. (1969). Iodopyracet transport by isolated perfused flounder proximal renal tubules. Am. J. Physiol. 217, 1053-1056.

Burger, J. W., and Hess, W. N. (1960). Function of the rectal gland of the spiny dogfish. Science 131, 670-671.

Burgess, D. W., Miarczynski, M. D., O'Donnell, M. J., and Wood, C. M. (2000). $\mathrm{Na}+$ and $\mathrm{Cl}-$ transport by the urinary bladder of the freshwater rainbow trout (Oncorhynchus mykiss). J. Exp. Zool. 287, 1-14.

Catches, J. S., Burns, J. M., Edwards, S. L., and Claiborne, J. B. (2006). Na+/H+ antiporter, $\mathrm{V}-\mathrm{H}+$-ATPase and $\mathrm{Na}+$ / $\mathrm{K}+$-ATPase immunolocalization in a marine teleost (Myoxocephalus octodecemspinosus). J. Exp. Biol. 209, 3440-3447.

Chambers, R., and Kempton, R. T. (1933). Indications of function of the chick mesonephros in tussue culture with phenol red. J. Cell. Comp. Physiol. 3, 131-137.

Choe, K. P., Edwards, S. L., Claiborne, J. B., and Evans, D. H. (2007). The putative mechanism of $\mathrm{Na}(+)$ absorption in euryhaline elasmobranchs exists in the gills of a stenohaline marine elasmobranch, Squalus acanthias. Comp. Biochem. Physiol., Part A Mol. Integr. Physiol. 146, 155-162.

Choe, K. P., Morrison-Shetlar, A. I., Wall, B. P., and Claiborne, J. B. (2002). Immunological detection of $\mathrm{Na}^{+} / \mathrm{H}^{+}$ exchangers in the gills of a hagfish, Myxine glutinosa, an elasmobranch, Raja erinacea, and a teleost, Fundulus heteroclitus. Comp. Biochem. Physiol., Part A Mol. Integr. Physiol. 131, 375-385.

Claiborne, J. B., Blackston, C. R., Choe, K. P., Dawson, D. C., Harris, S. P., Mackenzie, L. A., and MorrisonShetlar, A. I. (1999). A mechanism for branchial acid excretion in marine fish: identification of multiple $\mathrm{Na}+/$ $\mathrm{H}+\operatorname{antiporter}(\mathrm{NHE})$ isoforms in gills of two seawater teleosts. J. Exp. Biol. 202, 315-324.

Claiborne, J. B., Edwards, S. L., and Morrison-Shetlar, A. I. (2002). Acidbase regulation in fishes: cellular and molecular mechanisms. J. Exp. Zool. 293, 302-319.

Claiborne, J. B., and Evans, D. H. (1988). Ammonia and acid-base balance during high ammonia exposure in a marine teleost (Myoxocephalus octodecimspinosus). J. Exp. Biol. 140, 89-105.

Cliff, W. H., Sawyer, D. B., and Beyenbach, K.W. (1986). Renal proximal tubule of flounder II. Transepithelial Mg secretion. Am. J. Physiol. 250, R616-R624.

Cutler, C. P., and Cramb, G. (2008). Differential expression of absorptive cation-chloride-cotransporters in the intestinal and renal tissues of the European eel (Anguilla anguilla).

facilities at Friday Harbor, WA, USA; Bamfield, BC, USA; Pacific Grove, CA, USA and Woods Hole, MA, USA) has facilitated discussions, techniques, and experiments that have played a major role in our current knowledge of osmoregulation and epithelial transport. It is hoped the next 80 years will continue this tradition.

\section{ACKNOWLEDGMENT}

The support of the National Science Foundation (most recently, IOB-0519579) is gratefully acknowledged. The author acknowledges Leon Goldstein who first suggested that he come to the MDIBL to continue his research in fish osmoregulation.

Comp. Biochem. Physiol. B, Biochem. Mol. Biol. 149, 63-73.

Dawson, D. C., and Andrew, D. (1979). Differential inhibition of $\mathrm{NaCl}$ absorption and short-circuit cuirrent in the urinary bladder of the winter flounder, Pseudopleuronectes americanus. Bull. Mt. Desert Isl. Biol. Lab. Salisb. Cove Maine 19, 46-49.

Degnan, K. J., Karnaky, K. J., Jr., and Zadunaisky, J. (1977). Active chloride transport in the in vitro opercular skin of a teleost (Fundulus heteroclitus), a gill-like epithelium rich in chloride cells. J. Physiol. (Lond). 271, 155-191.

Demarest, J. R. (1984). Ion and water transport by the flounder urinary bladder: salinity dependence. Am. J. Physiol. 246, F395-F401.

Diamond, J.M. (1962). The mechanism of solute transport by the gall-bladder. $J$. Physiol. (Lond). 161, 474-502.

Diamond, J.M. (2004). Collapse. Viking Press. 592.

Djurisic, M., Isenring, P., and Forbush, B. (2003). Cloning, tissue distribution and changes during salt adaptation of three $\mathrm{Na}-\mathrm{K}-\mathrm{Cl}$ cotransporter isoforms from killifish, Fundulus heteroclitus. Bull. Mt. Desert Isl. Biol. Lab. Salisb. Cove Maine 42, 89-90.

Edwards, S., Weakley, J., Diamanduros, A., and Claiborne, J. (2010). Molecular identification of $\mathrm{Na}^{+} / \mathrm{H}^{+}$exchanger isoforms (NHE2) in the gills of the euryhaline teleost Fundulus heteroclitus. J. Fish Biol. 76, 415-426.

Epstein, F. H. (1998). A Laboratory by the Sea. The Mount Desert Island Biological Laboratory: 1898-1998. Rhinebeck, NY: The River Press.

Evans, D. H. (1975). Ionic exchange mechanisms in fish gills. Comp. Biochem. Physiol. 51A, 491-495.

Evans, D. H. (1977). Further evidence for $\mathrm{Na} / \mathrm{NH} 4$ exchange in marine teleost fish. J. Exp. Biol. 70, 213-220.

Evans, D.H. (1984). “The roles of gill permeability and transport mechanisms in euryhalinity," in Fish Physiology, vol. XB, eds. W. S. Hoar and D. J. Randall (Orlando: Academic Press), 239-283.

Evans, D. H. (2001). Vasoactive receptors in abdominal blood vessels of the dog- fish shark, Squalus acanthias. Physiol. Biochem. Zool. 74, 120-126.

Evans, D.H. (2002). Cell signaling and ion transport across the fish gill epithelium. J. Exp. Zool. 293, 336-347.

Evans, D.H. (2008). Teleost fish osmoregulation: what have we learned since August Krogh, Homer Smith, and Ancel Keys? Am. J. Physiol. Regul. Integr. Comp. Physiol. 295, R704-R713.

Evans, D. H. (2010). Fish gill ion uptake: August Krogh to morpholinos. Acta Physiol. (in press).

Evans, D. H., and Claiborne, J. B. (2009). "Osmotic and ionic regulation in fishes," in Osmotic and Ionic Regulation: Cells and Animals, ed. D. H. Evans (Boca Raton: CRC Press), 295-366.

Evans, D. H., and Cooper, K. (1976). The presence of $\mathrm{Na}-\mathrm{Na}$ and $\mathrm{Na}-\mathrm{K}$ exchange in sodium extrusion by three species of fish. Nature 259, 241-242.

Evans, D.H., Kormanik, G.A., and Krasny, E. Jr. (1979). Mechanisms of ammonia and acid extrusion by the little skate Raja erinacea. J. Exp. Zool. 208, 431-437.

Evans, D. H., and Piermarini, P.M. (2001). Contractile properties of the elasmobranch rectal gland. J. Exp. Biol. 204, 59-67.

Evans, D. H., Piermarini, P. M., and Choe, K. P. (2005). The multifunctional fish gill: dominant site of gas exchange, osmoregulation, acid-base regulation, and excretion of nitrogenous waste. Physiol. Rev. 85, 97-177.

Evans, D. H., Rose, R. E., Roeser, J. M., and Stidham, J. D. (2004). NaCl transport across the opercular epithelium of Fundulus heteroclitus is inhibited by an endothelin to NO, superoxide, and prostanoid signaling axis. Am. J. Physiol. Regul. Integr. Comp. Physiol. 286, R560-R568.

Field, M., Karnaky, K. J. Jr., Smith, P. L., Bolton, J. E., and Kinter, W. B. (1978). Ion transport across the isolated intestinal mucosa of the winter flounder, Pseudopleuronectes americana. I. Functional and structural properties of cellular and paracellular pathways for Na and Cl. J. Membr. Biol. 41, 265-293. 
Forrest, J. N. Jr. (1996). Cellular and molecular biology of chloride secretion in the shark rectal gland: regulation by adenosine receptors. Kidney Int. 49, 1557-1562.

Forster, R., and Taggart, J. (1950). Use of isolated renal tubules for the examination of metabolic processes associated with active cellular transport. J. Cell Comp. Physiol. 36, 251-270.

Forster, R. P. (1977). My forty years at the Mount Desert Island Biological Laboratory. J. Exp. Zool. 199, 299-307.

Fortier,J., Diamanduros, A. W., Claiborne, J. B., Hyndman, K. A., Evans, D. H., and Edwards, S. L. (2008). Molecular characterization of NHE8 in the sea lamprey, Petromyzon marinus. Bull. Mt. Desert Isl. Biol. Lab. Salisb. Cove Maine 47, 26-27.

Frizzell, R. A., Field, M., and Schultz, S. G. (1979a). Sodium-coupled chloride transport by epithelial tissues. Am. J. Physiol. 236, F1-F8.

Frizzell, R. A., Smith, P. L., and Field, M. (1981). "Sodium chloride absorption by flounder intestine: a model for the renal thick ascending limb," in Membrane Biophysics: Structure and Function in Epithelia, eds. M. Dinno and A. Callahan (New York: Alan R. Liss), 67-81.

Frizzell, R. A., Smith, P. L., Vosburgh, E., and Field, M. (1979b). Coupled sodium-chloride influx across brush border of flounder intestine. J. Membr. Biol. 46, 27-39.

Gamba, G., Saltzberg, S. N., Lombardi, M., Miyanoshita, A., Lytton, J., Hediger, M. A., Brenner, B. M., and Hebert, S. C. (1993). Primary structure and functional expression of a cDNA encoding the thiazide-sensitive, electroneutral sodium-chloride cotransporter. Proc. Natl. Acad. Sci. U.S.A. 90, 2749-2753.

Grantham, J. J., and Wallace, D. P. (2002). Return of the secretory kidney. Am. J. Physiol. Renal Physiol. 282, F1-F9.

Greger,R., and Schlatter,E. (1981).Presence of luminal $\mathrm{K}+$, a prerequisite for active $\mathrm{NaCl}$ transport in the cortical thick ascending limb of Henle's loop of rabbit kidney. Pflugers Arch. 392, 92-94.

Greger, R., Schlatter, E., and Gogelein, H. (1986). Sodium chloride secretion in rectal gland of dogfish, Squalus acanthias. News Physiol. Sci. 1, 134-136.

Grosell, M. (2006). Intestinal anion exchange in marine fish osmoregulation. J. Exp. Biol. 209, 2813-2827.

Grosell, M., Genz, J., Taylor, J., Perry, S., and Gilmour, K. (2009). The involvement of $\mathrm{H}+$-ATPase and carbonic anhydrase in intestinal $\mathrm{HCO}_{-}$ secretion in seawater-acclimated rainbow trout. J. Exp. Biol. 212, 1940-1948.
Grosell, M., and Taylor, J. R. (2007). Intestinal anion exchange in teleost water balance. Comp. Biochem. Physiol., Part A Mol. Integr. Physiol. 148, 14-22.

Grzelczak, Z., Alon, N., Fahim, S., Dubel, S., Collins, F. S., Tsui, L.-C., and Riordan, J. (1990). The molecular cloning of a CFTR homologue from shark rectal gland. Pediatr. Pulmonol. Suppl. 5, 95 .

Haas, M., Schmidt, W. F., and McManus, T.J.(1982).Catecholamine-stimulated ion transport in duck red cells. Gradient effects in electrically neutral $[\mathrm{Na}+\mathrm{K}+2 \mathrm{Cl}]$ Co-transport. J. Gen. Physiol. 80, 125-147.

Halm, D. R., Krasny, E. J.Jr., and Frizzell, R. A. (1985). Electrophysiology of flounder intesstinal mucosa I. Conductance properties of the cellular and paracellular pathways. J. Gen. Physiol. 85, 843-864.

Hanrahan, J. W., Mathews, C. J., Grygorczyk, R., Tabcharani, J. A., Grzelczak, Z., Chang, X. B., and Riordan, J. R. (1996). Regulation of the CFTR chloride channel from humans and sharks. J. Exp. Zool. 275, 283-291.

Hayslett, J. P., Schon, D. A., Epstein, M., and Hogben, C. A. (1974). In vitro perfusion of the dogfish rectal gland. Am. J. Physiol. 226, 1188-1192.

Hebert, S. C., and Gullans, S. R. (1995). The electroneutral sodium(potassium)-chloride co-transporter family: a journey from fish to the renal co-transporters. Curr. Opin. Nephrol. Hypertens. 4, 389-391.

Hebert, S. C., Mount, D. B., and Gamba, G. (2004). Molecular physiology of cation-coupled $\mathrm{Cl}^{-}$cotransport: the SLC12 family. Pflugers Arch. 447, 580-593.

Hilden, S., and Hokin, L. E. (1975). Active potassium transport coupled to active sodium transport in vesicles reconstituted from purified sodium and potassium ion-activated adenosine triphosphatase from the rectal gland of Squalus acanthias. J. Biol. Chem. 250, 6296-6303.

Hwang, P. P. (2009). Ion uptake and acid secretion in zebrafish (Danio rerio). J. Exp. Biol. 212, 1745-1752.

Hwang, P. P., and Lee, T. H. (2007). New insights into fish ion regulation and mitochondrion-rich cells. Comp. Biochem. Physiol. A Mol. Integr. Physiol. 48, 479-497.

Hyndman, K. A., and Evans, D. H. (2009) Short-term low-salinity tolerance by the longhorn sculpin, Myoxocephalus octodecimspinosus. J. Exp. Zool. 311A, $45-56$.

Jampol, L. M., and Epstein, F. H. (1970). Sodium-potassium-activated adenosine triphosphatase and osmotic regulation by fishes. Am. J. Physiol. 218 607-611.

Kamiya, M. (1972). Sodium-potassiumactivated adenosinetriphosphatase in isolated chloride cells from eel gills. Comp. Biochem. Physiol. 43B 611-617.

Kaplan, M. R., Mount, D. B., Delpire, E., Gamba, G., and Hebert, S. C. (1996) Molecular mechanisms of $\mathrm{NaCl}$ cotransport. Ann. Rev. Physiol. 58, 649-668.

Karnaky, K. G. Jr., and Kinter, W. B. (1977). Killifish opercular skin: a flat epithelium with a high density of chloride cells. J. Exp. Zool. 199, 355-364.

Karnaky, K. J. Jr. (1998). "Osmotic and ionic regulation," in The Physiology of Fishes, ed. D. H. Evans (Boca Raton CRC Press), 157-176.

Karnaky, K. J. Jr. (2008). From form to function/Homer Smith to CFTR: salt secretion across epithelia from the perspective of the teleost chloride cell. Bull. Mt. Desert Isl. Biol. Lab. Salisb. Cove Maine 47, 1-10.

Karnaky, K. J. Jr., Kinter, L. B., Kinter, W. B., and Stirling, C. E. (1976). Teleost chloride cell. II. Autoradiographic localization of gill $\mathrm{Na}$,K-ATPase in killifish Fundulus heteroclitus adapted to low and high salinity environments. $J$. Cell. Biol. 70, 157-177.

Karnaky, K. J. Jr., Valentich, J. D., Currie, M. G., Oehlenschlager, W. F., and Kennedy, M. P. (1991). Atriopeptin stimulates chloride secretion in cultured shark rectal gland cells. Am. J. Physiol. 260, C1125-C1130.

Kelley, G. G., Poeschla, E. M., Barron, H. V., and Forrest, J. N. Jr. (1990). Al adenosine receptors inhibit chloride transport in the shark rectal gland. Dissociation of inhibition and cyclic AMP. J. Clin. Invest. 85 , 1629-1636.

Keys, A. (1931). Chloride and water secretion and absorption by the gills of the eel. Z. Vgl. Physiol. 15, 364-389.

Keys, A. B., and Willmer, E. N. (1932). "Chloride-secreting cells" in the gills of fishes with special reference to the common eel. J. Physiol. (Lond). 76, 368-378.

Kirschner, L. B., Greenwald, L., and Kerstetter, T. H. (1973). Effect of amiloride on sodium transort across body surfaces of fresh water animals. Am. J. Physiol. 224, 832-837.

Krogh, A. (1937). Osmotic regulation in freshwater fishes by active absorption of chloride ions. Z. Vgl. Physiol. 24 656-666.

Krogh, A. (1938). The active absorption of ions in some freshwater animals. $Z$. Vgl. Physiol. 25, 335-350.
Krogh, A. (1939). Osmotic Regulation in Aquatic Animals. Cambridge: Cambridge University Press.

Lahlou, B., Henderson, I. W., and Sawyer, W. H. (1969). Renal adaptations by Opsanus tau, a euryhaline aglomerular teleost, to dilute media. Am. J. Physiol. 216, 1266-1272.

Loretz, C. A., and Fourtner, C. R. (1988). Functional characterization of a voltage-gated anion channel from teleost fish intestinal epithelium. J. Exp. Biol. 136, 383-403.

Lorin-Nebel, C., Boulo, V., Bodinier, C., and Charmantier, G. (2006). The $\mathrm{Na}+$ / $\mathrm{K}+/ 2 \mathrm{Cl}$ - cotransporter in the sea bass Dicentrarchus labrax during ontogeny: involvement in osmoregulation. J. Exp. Biol. 209, 4908-4922.

Lytle, C., Xu, J. C., Biemesderfer, D., Haas, M., and Forbush, B. 3rd. (1992). The $\mathrm{Na}-\mathrm{K}-\mathrm{Cl}$ cotransport protein of shark rectal gland. I. Development of monoclonal antibodies, immunoaffinity purification, and partial biochemical characterization. J. Biol. Chem. 267, 25428-25437.

Maetz, J. (1969). Sea water teleosts: evidence for a sodium-potassium exchange in the branchial sodium-excreting pump. Science $166,613-615$

Marshall, E. K. (1930). A comparison of the function of the glomerular and aglomerular kidney. Am. J. Physiol. 94, 1-10.

Marshall, E. K., and Smith, H. W. (1930). The glomerular development of the vertebrate kidney in relation to habitat. Biol. Bull. 59, 135-153.

Marshall, J., Martin, K. A., Picciotto, M., Hockfield, S., Nairn, A. C., and Kaczmarek, L. K. (1991). Identification and localization of a dogfish homolog of human cystic fibrosis transmembrane conductance regulator. J. Biol. Chem. 266, 22749-22754.

Marshall,W.(1986).Independent $\mathrm{Na}$ and $\mathrm{Cl}^{-}$active transport by urinary bladder epithelium of brook trout. Am. J. Physiol. Regul. Integr. Comp. Physiol. 250, 227-234

Marshall,W.S., and Grosell,M. (2006). “Ion transport,osmoregulation andacid-base balance," in The Physiology of Fishes, eds. D. H. Evans and J. B. Claiborne, (Boca Raton: CRC Press), 177-230.

Marshall, W. S., Howard, J. A., Cozzi, R. R., and Lynch, E. M. (2002). $\mathrm{NaCl}$ and fluid secretion by the intestine of the teleost Fundulus heteroclitus: involvement of CFTR. J. Exp. Biol. 205, 745-758.

McCormick, S.D. (2001). Endocrine control of osmoregulation in teleost fish. Am. Zool. 41, 781-794.

McRoberts, J., Erlinger, S., Rindler, M., and Saier,M.J.(1982).Furosemide-sensitive 
salt transport in the Madin-Darby Canine Kidney cell line: Evidence for the cotransport of $\mathrm{Na}^{+}, \mathrm{K}^{+}$, and $\mathrm{Cl}^{-}$. J. Biol. Chem. 257, 2260-2266.

Mendelsohn, S. A., Cherksey, B. D., and Degnan, K. J. (1981). Adrenergic regulation of chloride secretion across the opercular epithelium: the role of cyclic AMP. J. Comp. Physiol. 145, 29-35.

Miller, D. S. (2002). Xenobiotic export pumps, endothelin signaling, and tubular nephrotoxicants - a case of molecular hijacking. J. Biochem. Mol. Toxicol. 16, 121-127.

Musch, M. W., Orellana, S. A., Kimberg, L. S., Field, M., Halm, D. R., Krasny, E. J. Jr., and Frizzell, R. A. (1982). $\mathrm{Na}+-\mathrm{K}+-\mathrm{Cl}-$ co-transport in the intestine of a marine teleost. Nature 300, 351-353.

Parks, S. K., Tresguerres, M., and Goss, G. G. (2007). Blood and gill responses to $\mathrm{HCl}$ infusions in the Pacific hagfish (Eptatretus stoutii). Can. J. Zool. 85, 855-862.

Perry, S. F., Vulesevic, B., Grosell, M., and Bayaa, M. (2009). Evidence that SLC26 anion transporters mediate branchial chloride uptake in adult zebrafish (Danio rerio). Am. J. Physiol. 297, R988-R997.

Philpott, C. W. (1965). Halide localization in the teleost chloride cell and its identification by selected area electron diffraction. Protoplasma 60, 7-23.

Piermarini, P.M., and Evans, D. H. (2001). Immunochemical analysis of the vacuolar proton-ATPase B-subunit in the gills of a euryhaline stingray (Dasyatis sabina): effects of salinity and relation to $\mathrm{Na}^{+} / \mathrm{K}^{+}$-ATPase. J. Exp. Biol. 204, 3251-3259.

Piermarini, P.M., Verlander,J.W., Royaux, I. E., and Evans, D. H. (2002). Pendrin immunoreactivity in the gill epithelium of a euryhaline elasmobranch. Am. J. Physiol. Regul. Integr. Comp. Physiol. 283, R983-R992.

Renfro, J. L. (1975). Water and ion transport by the urinary bladder of the teleost Pseudopleuronectes americanus. Am. J. Physiol. 228, 52-61.

Renfro, J. L. (1977). Interdependence of active $\mathrm{Na}+$ and $\mathrm{Cl}-$ transport by the isolated urinary bladder of the teleost, Pseudopleuronectes americanus. J. Exp. Zool. 199, 383-390.

Reuss, L., Segal, Y., and Altenberg, G. (1991). Regulation of ion transport across gallbladder epithelium. Ann. Rev. Physiol. 53, 361-373.

Riordan, J. R., Forbush, B. 3rd., and Hanrahan, J. W. (1994). The molecular basis of chloride transport in shark rectal gland. J. Exp. Biol. 196, 405-418.

Sargent, J. R., Thomson, A. J., and Bornancin, M. (1975). Activities and localization of succinic dehydrogenase and $\mathrm{Na}+/ \mathrm{K}+$-activated adenosine triphosphatase in the gills of fresh water and sea water eels. Comp. Biochem. Physiol. 51 B, 75-79.

Sawyer,D. B., and Beyenbach, K.W. (1985). Mechanism of fluid secretion in isolated shark renal proximal tubules. Am. J. Physiol. 249, F884-F890.

Schofield, J. P., Jones, D. S., and Forrest, J. N. Jr. (1991). Identification of C-type natriuretic peptide in heart of spiny dogfish shark (Squalus acanthias).Am. J. Physiol. 261, F734-F739.

Siegel, N. J., Schon, D. A., and Hayslett, J. P. (1976). Evidence for active chloride transport in dogfish rectal gland. Am. J. Physiol. 230, 1250-1254.

Silva, P., Epstein, F. H., Karnaky, K. J. Jr., Reichlin, S., and Forrest, J. N. Jr. (1993). Neuropeptide Y inhibits chloride secretion in the shark rectal gland. Am. J. Physiol. 265, R439-R446.

Silva, P., Lear, S., Reichlin, S., and Epstein, F. H. (1990a). Somatostatin mediates bombesin inhibition of chloride secretion by rectal gland. Am. J. Physiol. 258, R1459-R1463.

Silva, P., Solomon, R., Spokes, K., and Epstein, F. (1977a). Ouabain inhibition of gill Na-K-ATPase: relationship to active chloride transport. J. Exp. Zool. 199, 419-426.

Silva, P., Solomon, R. J., and Epstein, F. H. (1990b). Shark rectal gland. Meth. Enzymol. 192, 754-766.

Silva, P., Solomon, R. J., and Epstein, F. H. (1996). The rectal gland of Squalus acanthias: a model for the transport of chloride. Kidney Int. 49, 1552-1556.

Silva, P., Solomon, R. J., and Epstein, F. H. (1997). Transport mechanisms that mediate the secretion of chloride by the rectal gland of Squalus acanthias. J. Exp. Zool. 279, 504-508.

Silva, P., Stoff, J., Field, M., Fine, L., Forrest, J. N., and Epstein, F. H. (1977b). Mechanism of active chloride secretion by shark rectal gland: role of Na-K-ATPase in chloride transport. Am. J. Physiol. 233, F298-F306.

Silva, P., Stoff,J. S., Leone, D. R., and Epstein, F.H. (1985). Mode of action of somatostatin to inhibit secretion by shark rectal gland. Am. J. Physiol. 249, R329-R334.

Silva, P., Stoff, J. S., Solomon, R. J., Lear, S., Kniaz, D., Greger, R., and Epstein, F. H. (1987). Atrial natriuretic peptide stimulates salt secretion by shark rectal gland by releasing VIP. Am. J. Physiol. 252, F99-F103.

Smith, H. W. (1930). The absorption and excretion of water and salts by marine teleosts. Am. J. Physiol. 93, 480-505.

Smith, H.W. (1931). The absorption and secretion of water and salts by the elasmobranch fishes. II. Marine elasmobranchs. Am. J. Physiol. 98, 296-310.
Solomon, R., Taylor, M., Sheth, S., Silva, P., and Epstein, F. H. (1985). Primary role of volume expansion in stimulation of rectal gland function. Am. J. Physiol. 248, R638-R640.

Stoff, J. S., Rosa, R., Hallac, R., Silva, P., and Epstein, F. H. (1979). Hormonal regulation of active chloride transport in the dogfish rectal gland. Am. J. Physiol. 237, 138-144.

Stokes, J. B. (1984). Sodium chloride absorption by the urinary bladder of the winter flounder: a thiazidesensitive, electrically neutral transport system. J. Clin. Invest. 74, 7-16.

Sullivan, S. K., Swamy, K., and Field, M. (1991). cAMP-activated C1 conductance is expressed in Xenopus oocytes by injection of shark rectal gland mRNA. Am. J. Physiol. 260, C664-C669.

Suvitayavat, W., Dunham, P. B., Haas, M. and Rao,M.C.(1994).Characterization of the proteins of the intestinal $\mathrm{Na}(+)-\mathrm{K}(+)-2 \mathrm{Cl}-$ cotransporter. $\mathrm{Am}$. J. Physiol. 267, C375-C384.

Suzuki, Y., Itakura, M., Kashiwagi, M., Nakamura, N., Matsuki, T., Sakuta, H., Naito, N., Takano, K., Fujita, T., and Hirose, S. (1999). Identification by differential display of a hypertonicityinducible inward rectifier potassium channel highly expressed in chloride cells. J. Biol. Chem. 274, 11376-11382.

Tang, C.-H., Hwang, L.-Y., and Lee, T.-H. (2010). Chloride channel ClC-3 in gills of the euryhaline teleost, Tetraodon nigroviridis: expression, localization, and the possible role of chloride absorption. J. Exp. Biol. 213 , 683-693.

Taylor, J. R., Mager, E. M., and Grosell, M. (2010). Basolateral NBCel plays a rate-limiting role in transepithelial intestinal $\mathrm{HCO} 3-$ secretion, contributing to marine fish osmoregulation. J. Exp. Biol. 213, 459-468.

Tresguerres, M., Katoh, F., Fenton, H. Jasinska, E., and Goss, G. G. (2005). Regulation of branchial V-H(+)ATPase, $\mathrm{Na}(+) / \mathrm{K}(+)$-ATPase and NHE2 in response to acid and base infusions in the Pacific spiny dogfish (Squalus acanthias). J. Exp. Biol. 208, 345-354.

Tresguerres, M., Parks, S. K., and Goss, G. G. (2006). V-H(+)-ATPase, $\mathrm{Na}(+) /$ $\mathrm{K}(+)$-ATPase and NHE2 immunoreactivity in the gill epithelium of the Pacific hagfish (Epatretus stoutii). Comp. Biochem. Physiol., Part A Mol. Integr. Physiol. 145, 312-321.

Tsui, T. K. N., Hung, C. Y. C., Nawata, C. M., Wilson, J. M., Wright, P. A., and Wood, C. M. (2009). Ammonia transport in cultured gill epithelium of freshwater rainbow trout: the importance of Rhesus glycoproteins and the presence of an apical $\mathrm{Na}+/ \mathrm{NH} 4+$ exchange complex. J. Exp. Biol. 212, 878-892.

Venkatasubramanian, J., Ao, M., and Rao, M.C. (2010). Ion transport in the small intestine.Curr. Opin. Gastroenterol. 26, 123-128.

Waldegger, S., Fakler, B., Bleich, M., Barth, P., Hopf, A., Schulte, U., Busch, A. E. Aller, S. G., Forrest, J. N. Jr., Greger, R., and Lang, F. (1999). Molecular and functional characterization of s-KCNQ1 potassium channel from rectal gland of Squalus acanthias. Pflugers Arch. 437, 298-304.

Weihrauch, D., Wilkie, M. P., and Walsh, P. J. (2009). Ammonia and urea transporters in gills of fish and aquatic crustaceans. J. Exp. Biol. 212, 1716-1730.

Wilkie, M. P. (2002). Ammonia excretion and urea handling by fish gills: present understanding and future research challenges. J. Exp. Zool. 293, 284-301.

Wright, P. A., and Wood, C. M. (2009). A new paradigm for ammonia excretion in aquatic animals: role of Rhesus (Rh) glycoproteins. J. Exp. Biol. 212, 2303-2312.

Wu, S.-C., Horng, J.-L., Liu, S.-T., Hwang, P.-P., Wen, Z.-H., Lin, C.-S., and Lin, L.-Y. (2010). Ammonium-dependent sodium uptake in mitochondrion-rich cells of medaka (Oryzias latipes) larvae. Am. J. Physiol., Cell. Physiol. 298 C237-C250.

Xu, J. C., Lytle, C., Zhu, T. T., Payne, J. A., Benz, E., Jr., and Forbush, B. 3rd. (1994). Molecular cloning and functional expression of the bumetanidesensitive $\mathrm{Na}-\mathrm{K}-\mathrm{Cl}$ cotransporter. Proc. Natl. Acad. Sci. U.S.A. 91, 2201-2205.

Conflict of Interest Statement: The author declares that the research was conducted in the absence of any commercial or financial relationships that could be construed as a potential conflict of interest.

Received: 05 May 2010; paper pending published: 27 May 2010; accepted: 28 May 2010; published online: 18 June 2010. Citation: Evans DH (2010) A brief history of the study of fish osmoregulation: the central role of the Mt. Desert Island Biological Laboratory. Front. Physio. 1:13. doi: 10.3389/fphys.2010.00013

This article was submitted to Frontiers in Aquatic Physiology, a specialty of Frontiers in Physiology.

Copyright $(\odot) 2010$ Evans. This is an openaccess article subject to an exclusive license agreement between the authors and the Frontiers Research Foundation, which permits unrestricted use, distribution, and reproduction in any medium, provided the original authors and source are credited. 